\title{
IMPLEMENTASI ELECTRONIC FILING (E-FILING) DALAM MENDUKUNG PELAYANAN ADMINISTRASI
}

\author{
Mira Veranita
}

\author{
Politeknik Piksi Ganesha Bandung
}

E-mail : $\underline{\text { mirave2198@gmail.com }}$

\begin{abstract}
ABSTRAK
Tiap organisasi baik itu organisasi publik maupun organisasi bisnis pasti menghasilkan arsip sebagai hasil sertaan (output) dari berbagai aktivitasnya.

Implementasi Electronic Filing (E-Filing) yang baik dalam sebuah organisasi dibutuhkan untuk mendukung efektivitas dan efisiensi pelayanan administrasi, karena arsip yang diterima oleh organisasi saat ini bukan hanya arsip cetak namun justru lebih banyak arsip elektronik (electronic records), baik melalui e-mail, menggunakan media CD, DVD, microfilm, dan media elektronik lainnya.

Jenis penelitian ini adalah Penelitian Deskriptif Kualitatif, dengan teknik pengumpulan data wawancara, observasi dan studi dokumentasi, dengan teknik analisis domain.

Hasil analisa dalam studi kasus yang dilakukan menunjukkan bahwa Implementasi E-Filing di PT Elite Advertising Bandung sangat mendukung pelayanan administrasi, karena memudahkan penyimpanan, memudahkan pencarian, menghemat pengeluaran organisasi, memperluas penyebaran (share), menghemat tenaga kerja (SDM), memudahkan recovery dan back up, dan memudahkan pengambilan keputusan oleh pimpinan, sehingga terbukti sangat membantu dalam meningkatkan pelayanan administrasi perkantoran. Implementasi E-Filing meliputi : pemindaian dokumen, penyimpanan dokumen, pengindeksan dokumen, penggunaan dan pelacakan, pengontrolan akses, retensi dan pelestarian arsip.
\end{abstract}

Kata Kunci : Pengelolaan Arsip; Arsip Elektronik ; E-Filing; Administrasi; Pelayanan

\section{ABSTRACT}

Each organization, public or business generates archives as a result of its activities.

Implementation of good Electronic Filing System (E-Filing) within an organization needed to support the effectiveness and efficiency of administrative services, because the archives received by organizations today is not only the printed-records but instead more electronic records, either via e-mail , using media CDs, DVDs, microfilm and other electronic media.

This research is a qualitative descriptive study, with data collection technique of interview, observation and documentation, and domain analysis techniques.

The results show that the implementation of E-Filing in PT Elite Advertising Bandung very supportive administrative services, for easy storage, facilitate the search, save the organization, expand distribution (share), saves labor (HR), facilitate recovery and backing up, and facilitate decision-making by the leadership, so it proved to be very helpful in improving administrative services offices.

Implementation of E-Filing include: document scanning, document storage, document indexing, use and tracking, access control, retention and preservation of archives.

Keywords : Records Management ; Electronic archives ; E-Filing ; administration ; service

\section{PENDAHULUAN}

Arsip merupakan hal yang tidak dapat dianggap sepele dalam aktivitas organisasi publik maupun perusahaan-perusahaan bisnis. Dalam aktivitasnya setiap organisasi yang berkembang apalagi organisasi maju akan menghasilkan banyak data, berkas maupun dokumendokumen berupa surat, formulir, laporan-laporan, produkproduk perkantoran lain (office work).

Selain sebagai sarana informasi, arsip juga sangat menunjang kemajuan sebuah organisasi. Pada sebagian besar lembaga atau organisasi, arsip diperlukan untuk membantu sistem pelayanan baik secara eksternal maupun internal, selain itu arsip merupakan instrumen yang jika dikelola dengan baik akan sangat mempengaruhi kelancaran administrasi pada suatu organisasi atau lembaga, oleh karena itu pengelolaan arsip sangat dibutuhkan untuk membantu terwujudnya kelancaran proses administrasi kantor.

Salah satu usaha mendukung pelayanan administrasi yang efektif dan efisien adalah E-Filing, yang saat ini lebih banyak digunakan oleh organisasi-organisasi swasta. Padahal kebutuhan dan kepentingan pengelolaan arsip dan layanan dokumen secara elektronik ( E-Filing) di organisasi-organisasi pemerintah dan kantor-kantor pelayanan publik sudah cukup tinggi.

Pengelolaan arsip dengan cara manual dan konvensional cukup banyak menyita tenaga, membutuhkan banyak sarana dan tempat dan waktu yang cukup lama dalam penemuan kembali sebuah arsip (record).

Agar kegiatan-kegiatan administrasi di organisasi berlangsung dengan lancar perlu dilakukan pengelolaan terhadap produk-produk administrasi secara efektif, sejak arsip mulai tercipta (diterima), disimpan, dan dipelihara sampai arsip dimusnahkan, serta pemilihan peralatan yang tepat untuk menyimpan arsip.

E-Filing diharapkan menjadi solusi bagi organisasiorganisasi publik untuk meningkatkan pelayanan kepada publik yang memerlukan informasi. 


\section{KAJIAN PUSTAKA}

\section{A. E-Filing}

Kata arsip yang dalam bahasa Inggris dikenal records, dan dalam bahasa Belanda dikenal dengan istilah archief berasal dari kata Archivum (Yunani) yang artinya tempat penyimpanan, sering juga dihubung-hubungkan dengan kata Archeon yang berarti Balaikota, yaitu tempat penyimpanan dokumen. Menurut Gina Madiana dan Iwan Setiawan (1994:33) : "arsip dapat diartikan suatu tanda bukti, dokumen atau warkat yang bertalian dengan bukti keterangan suatu keluarga, perusahaan, masyarakat atau bangsa."

Chrisyanti (2011:74) memberikan definisi arsip sebagai "catatan tertulis dalam bentuk gambar ataupun bagan yang memuat keterangan-keterangan mengenai sesuatu subyek (pokok persoalan) ataupun peristiwa yang dibuat orang untuk membantu daya ingatan orang (itu) pula". Lebih komprehensif, Amsyah (2003:3) memberikan pengertian arsip sebagai " setiap catatan (record atau warkat) yang tertulis, tercetak, atau ketikan, dalam bentuk huruf, angka atau gambar, yang mempunyai arti dan tujuan tertentu sebagai bahan komunikasi dan informasi, yang terekam pada kertas (kartu, formulir), kertas film (slide, film-strip, micro-film), media komputer (pita tape, piringan, rekaman, disket), kertas photo copy, dan lain-lain."

Berdasarkan UU Nomor 7 tahun 1971 tentang Ketentuan-ketentuan Pokok Kearsipan, pasal 1 ayat a dan b, menetapkan bahwa yang dimaksud dengan arsip adalah :

a. Naskah-naskah yang dibuat dan diterima oleh Lembaga-lembaga Negara dan Badan-badan Pemerintahan dalam bentuk corak apapun, baik dalam keadaan tunggal maupun berkelompok, dalam rangka kegiatan pemerintahan.

b. Naskah-naskah yang dibuat dan diterima oleh Badan-badan Swasta dan atau perorangan, dalam bentuk corak apapun, baik dalam keadaan tunggal maupun berkelompok, dalam rangka pelaksanaan kehidupan kebangsaan.

Peranan arsip sebagai pusat ingatan, sumber informasi dan sebagai alat pengawasan sangat diperlukan dalam setiap organisasi dalam rangka kegiatan perencanaan, penganalisaan, pengembangan, perumusan kebijaksanaan, pengambilan keputusan, pembuatan laporan, pertanggungjawaban, penilaian dan pengendalian. Agar terwujud sistem dan prosedur kerja yang baik di bidang kearsipan, perlu dilakukan pengelolaan arsip yang tepat.

Haryadi (2009:52) menjelaskan "arsip elektronis (Electronic-File) adalah kumpulan data yang disimpan dalam bentuk data scan-an yang dipindahkan secara elektronik atau dilakukan digital copy menggunakan resolusi tinggi, kemudian disimpan dalam hard drive atau optical disk."

Menurut National Archives and Record Administration (NASA) USA “Arsip elektronik ( $E$ File) merupakan arsip-arsip yang disimpan dan diolah di dalam suatu format, dimana hanya computer yang dapat memprosesnya. Oleh karenanya arsip elektronik seringkali dikatakan machine-readable record."
Menurut Budiman (2009:5) Proses penciptaan arsip dapat dilakukan dengan 2 (dua) cara :

1) Penciptaan secara elektronik atau otomatisasi Penciptaan secara elektronik atau otomatisasi adalah menciptakan arsip elektronik dengan menggunakan alat yang bersifat elektronik, seperti camera digital, perekam suara, perekam video, dan khususnya komputer.

2) Penciptaan arsip dengan cara transformasi digital

Proses penciptaan arsip dengan transformasi digital sering disebut proses digitalisasi, yaitu proses penciptaan arsip elektronik dari arsip konvensional dengan tujuan untuk melindungi arsip konvensional dari kerusakan secara fisik.

Keuntungan E-Filing adalah :

a. Proses penemuan dan penyajian informasi yang cepat dan lengkap.

b. Akses dan penggunaan informasi oleh lebih dari satu pengguna (multi user) dalam waktu yang bersamaan.

c. Penyimpanan informasi lebih terpusat

d. Memiliki keakuratan dalam penyimpanan yang tinggi.

Bentuk media rekod elektronik bermacam-macam dengan ketahanan penyimpanan yang berbeda-beda antara lain: Media magnetik (Magnetic Media), Disk magnetik (Magnetic Disk), Pita Magnetik (Magnetic Tape), Kaset (Cassette), Media Optik (Optical Disk). Jenis dan bentuk rekod elektronik juga bisa bermacam-macam seperti File Text, File Data, Database.

Langkah-langkah Penyimpanan E-File :

1. Pemeriksaan Dokumen

2. Pemberian Indeks dan Pencatatan Arsip

3. Pembuatan Cross Reference

\section{B. Pelayanan Administrasi}

Siagian dalam Silalahi (1989 : 9$)$ mengemukakan : "administrasi adalah keseluruhan proses pelaksanaan kegiatan yang dilakukan oleh dua orang atau lebih yang terlibat dalam suatu bentuk usaha kerjasama demi tercapainya tujuan yang ditentukan sebelumnya'.

Menurut Soetarto dan Soewarno dalam Akadun (2007 : 36) : "administrasi adalah suatu proses penyelenggaraan dan pengurusan segenap tindakan atau kegiatan dalam setiap usaha kerja sama sekelompok manusia untuk mencapai tujuan"

Intinya administrasi melingkupi seluruh kegiatan, dari pengaturan hingga pengurusan sekelompok orang yang memiliki differensiasi pekerjaan untuk mencapai suatu tujuan bersama.

Menurut Quible dalam dalam Haryadi (2009:3) ada 5 jenis fungsi pendukung administrasi dalam perkantoran :

1. Fungsi rutin, yaitu fungsi administrasi yang membutuhkan pemikiran minimal mencakup pengarsipan dan penggandaan. Biasanya fungsi ini dilaksanakan oleh staf administrasi yang bertanggungjawab atas kegiatan administrasi seharihari.

2. Fungsi teknis, yaitu fungsi administrasi yang membutuhkan pendapat, keputusan dan keterampilan 
perkantoran yang memadai, seperti bisa menggunakan beberapa program aplikasi komputer. Fungsi ini biasanya dilakukan oleh staf administrasi yang tergabung dalam departemen teknologi informasi.

3. Fungsi analisis, yaitu fungsi yang membutuhkan pemikiran yang krisis dan kreatif, disertai dengan kemampuan untuk membuat keputusan.

4. Fungsi Interpersonal, yaitu fungsi yang membutuhkan penilaian dan analisis sebagai dasar pengambilan keputusan, serta keterampilan yang berhubungan dengan orang lain.

5. Fungsi manajerial, yaitu fungsi yang membutuhkan perencanaan, pengorganisasian, pengukuran dan pemotivasian, seperti pembuatan anggaran dan pengevaluasian karyawan.

Sebagai pusat administrasi, kantor menghasilkan (keluaran-output) biasanya dalam wujud kertas, arsip dan dokumen elektronik.

Seluruh proses administrasi yang dilakukan dalam perkantoran adalah proses layanan yang keluarannya (output) tertuju pada orang, kelompok orang, atau instansi lain. Di kantor yang bagaimanapun kecilnya terdapat dua macam pelayanan, pertama pelayanan ke dalam (pelayanan kepada manajemen), yang lain ialah pelayanan ke luar. Pelayanan ke dalam sifatnya menunjang pelaksanaan kegiatan pemenuhan kebutuhan organisasi. Namun demikian dari berbagai kegiatan pelayanan ke dalam banyak yang berdampak pada pelayanan keluar baik langsung maupun tidak langsung. Bahkan dalam kenyataannya pelayanan ke dalam itu merupakan rangkaian awal yang berlanjut pada pelayanan ke luar. Dapat dikatakan bahwa pelayanan ke dalam menjadi ukuran terhadap pelayanan ke luar. Jika pelayanan ke dalam cukup baik, lancar dan tertib, maka dapat diharapkan bahwa pelayanan ke luar akan tertib dan lancar pula. Seluruh proses pekerjaan administrasi tersebut merupakan rantai pelayanan yang keluarannya adalah pelayanan kepada orang, kelompok orang atau instansi yang berkepentingan.

Fungsi lain perkantoran adalah pusat data dan informasi. Fungsi ini dapat dilihat dari kegiatan perkantoran yang menghimpun data termasuk arsip dan informasi, baik untuk keperluan sendiri maupun pihak lain yang memerlukan. Pengertian informasi dalam kaitan dengan data, yaitu bahwa informasi adalah data yang telah diolah atau dianalisa sehingga mempunyai makna tertentu.

Dalam hubungan dengan tugas manajemen, data dan informasi mempunyai peranan penting sebagai :

1. Bahan bukti secara hukum

2. Bahan untuk penyelesaian masalah dan pengambilan keputusan

3. Bahan penulisan laporan

4. Bahan pendukung suatu rencana atau proyek

5. Bahan penelitian untuk antisipasi keadaan yang akan datang

Selain itu secara umum data dan informasi mempunyai peranan untuk membantu ingatan seseorang terhadap peristiwa atau kejadian yang telah lalu serta menjadi alat guna menyebarkan berita dan pengetahuan. Dengan peranan seperti itulah terutama data (arsip) dapat membuka jalan bagi penelitian mengenai masalah sehingga orang mengetahui apa yang terjadi pada masa itu kemudian dipelajari untuk pengembangan dan kemajuan masa sekarang (sejarah).

\section{F E N O M E N A}

1. Arsip merupakan keluaran (output) dari setiap organisasi.

2. Arsip yang diterima organisasi berupa arsip cetak dan saat ini sebagian besar berupa arsip elektronik.

3. Perlu dilakukan E-Filing untuk mengelola arsip yang diterima secara elektronik dan merubah arsip cetak menjadi arsip elektronik untuk meningkatkan pelayanan administrasi.

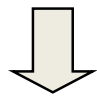

\section{KAJIAN TEORI}

1. UU Nomor 7 tahun 1971 tentang Ketentuan-ketentuan Pokok Kearsipan, pasal 1 ayat a dan b, menetapkan bahwa yang dimaksud dengan arsip adalah :

a) Naskah-naskah yang dibuat dan diterima oleh Lembaga-lembaga Negara dan Badan-badan Pemerintahan dalam bentuk corak apapun, baik dalam keadaan tunggal maupun berkelompok, dalam rangka kegiatan pemerintahan.

b) Naskah-naskah yang dibuat dan diterima oleh Badan-badan Swasta dan atau perorangan, dalam bentuk corak apapun, baik dalam keadaan tunggal maupun berkelompok, dalam rangka pelaksanaan kehidupan kebangsaan

2. Peranan arsip sebagai pusat ingatan, sumber informasi dan sebagai alat pengawasan sangat diperlukan dalam setiap organisasi dalam rangka kegiatan perencanaan, penganalisaan, pengembangan, perumusan kebijaksanaan, pengambilan keputusan, pembuatan laporan, pertanggungjawaban, penilaian dan pengendalian.

3. Arsip elektronis (Electronic-File) adalah kumpulan data yang disimpan dalam bentuk data scan-an yang dipindahkan secara elektronik atau dilakukan digital copy menggunakan resolusi tinggi, kemudian disimpan dalam hard drive atau optical disk." (Haryadi (2009:52)

4. Arsip elektronik (E-File) merupakan arsip-arsip yang disimpan dan diolah di dalam suatu format, dimana hanya computer yang dapat memprosesnya. Oleh karenanya arsip elektronik seringkali dikatakan machine-readable record." (National Archives and Record Administration (NASA) USA

5. Salah satu fungsi Administrasi perkantoran adalah sebagai pusat data dan informasi yang membutuhkan kecepatan dan ketepatan dalam penyediaan, penemuan kembali dan penyimpanan serta pemusnahan arsip.

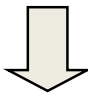

Implementasi E-Filing
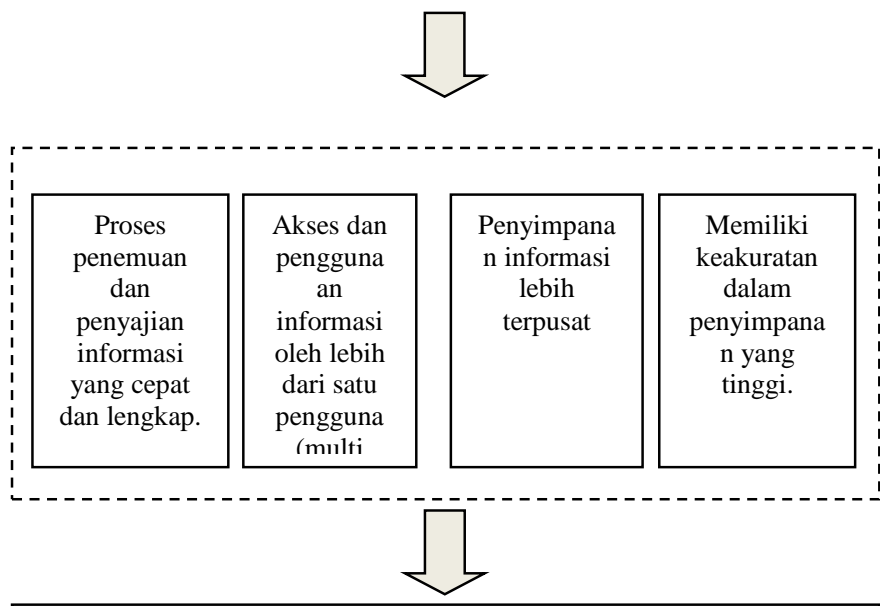

Efisiensi dan Efektivitas Pelayanan Administrasi

Kerangka Berpikir : 


\section{METODOLOGI}

Jenis penelitian ini adalah Penelitian Deskriptif kualitatif, yang dilaksanakan di PT. Elite Advertising sebuah Perusahaan Internasional di bidang periklanan, dilaksanakan selama kurang lebih 3 bulan, dari bulan Januari hingga Maret 2015, dengan responden seluruh karyawan pengelola dan pengguna arsip di bagian Administrasi.

Teknik Pengumpulan Data yang digunakan adalah wawancara, observasi dan studi dokumentasi. Teknik analisis data yang digunakan adalah Teknik analisis domain.

\section{HASIL DAN PEMBAHASAN}

Berdasarkan hasil penelitian ditemukan bahwa implementasi E-Filing di perusahaan ini sangat mendukung dalam pelayanan administrasi, karena mempermudah pekerjaan para pengelola arsip dalam mengolah, menyimpan dan menemukan kembali arsip yang akan dipergunakan juga mempermudah penyebaran informasi kepada para pengguna arsip.

E-Filing yang dilakukan melalui langkah-langkah sebagai berikut :

1) Pemindaian dokumen

Pemindaian dokumen adalah memindahkan dokumen baik yang diterima (untuk disimpan) maupun yang akan dikirim, dari bentuk hard file (print, cetak, hasil tik, tulisan tangan, foto, lukisan) ke dalam bentuk soft file.

Metode yang digunakan dalam pemindaian dokumen / arsip ini adalah dengan :

- Melakukan scanning, dengan menggunakan alat scanner untuk menghasilkan arsip elektronis.

- Melakukan conversion (konversi) dokumen Word Processor atau Spreadsheet menjadi data gambar permanen untuk disimpan pada sistem komputerisasi.

- Importing, yaitu memindahkan data secara elektronik seperti dokumen office (e-mail), grafik atau data video ke dalam sistem pengarsipan dokumen elektronik. Data dapat dipindahkan dengan melakukan drag and drop ke sistem dan tetap menggunakan format data aslinya.

\section{2) Penyimpanan Dokumen}

Setelah dilakukan pemindaian maka arsip disimpan secara benar dengan menggunakan sistem penyimpanan yang sudah ditentukan, yang mampu mengantisipasi perubahan teknologi baik hardware maupun software,juga mengantisipasi peningkatan jumlah dokumen dan bertahan dalam waktu cukup lama.

Untuk menghindari hilangnya arsip secara berkala dilakukan back up dan transfer ke media yang baru. Media penyimpanan yang dijadikan alternatif antara lain : Magnetic Media (hard drives), Magneto-Optical Storage, CD, DVD,WORM, Flash Disk, Micro $S D$ dan lain-lain.

Perangkat lunak (software) yang dipilih adalah software yang sudah tersedia di pasaran yang dibuat oleh Microsoft, Adobe, Linux selain juga program aplikasi khusus yang dibuat oleh perusahaan yang dikembangkan dan disesuaikan sendiri sesuai kebutuhan perusahaan untuk memproses data.

3) Dalam melakukan Pengindeksan Dokumen, diawali dengan mengklasifikasikan kategori sesuai sistem kategori yang berlaku. Pengindeksan arsip elektronik yang dilakukan hampir sama dengan arsip konvensional, hanya unit kerja menjadi fields dan subyek menjadi key words. Fields pada indeks dapat digunakan untuk mengkategorikan dokumen untuk melacak pembuatan atau retensi arsip atau untuk memasukkan subyek.

Metode dalam mengelola pengindeksan yang digunakan adalah Index Fields, yaitu menggunakan kata kunci misalnya nomor surat, tanggal pemindaian dan karakteristik lain.

4) Penggunaan dan Pelacakan Arsip (record) Arsip disimpan di tempat yang khusus agar tidak mudah rusak, terutama arsip-arsip digital dalam media $C D, F D$, MicroSD dan sejenisnya yang rentan rusak karena suhu.

Dasar pemilihan peralatan dan perlengkapan yang dipakai adalah kemampuan perusahaan dalam mengadakan dan menggunakan kebutuhan organisasi, perkembangan teknologi, adanya perbandingan spesifikasi produk, infrastruktur yang dimiliki serta ketersediaan barang di pasaran dan apakah barang tersebut compatible dengan peralatan lain yang sudah dimiliki.

Penggunaan arsip mencerminkan akses terhadap arsip dan status disposisi. Pelacakan terhadap penggunaan dan keberadaan arsip merupakan sistem keamanan organisasi. Pelacakan berfungsi untuk memastikan bahwa orang yang berhak yang diberi ijin untuk mengakses arsip tersebut. Dalam sistem $E$ Filing pelacakan penggunaan arsip secara otomatis akan ditangkap oleh transaksi sistem. Sistem pelacakan harus bisa memastikan lamanya waktu dan pergerakan rekod selalu terekam atau keberadaan rekod selalu terlacak.

5) Pengontrol akses (Pengawasan)

Petugas Pengurusan Arsip (arsiparis) melakukan kontrol akses yang komprehensif dan sederhana, dan mengendalikan dokumen apa yang bisa diakses, dilihat dan di copy bahkan diedit atau dihapus oleh pengguna.

Prosedur pengawasan arsip yang diterapkan terdiri dari : prosedur pengawasan pengelolaan arsip dan prosedur pengawasan pengelolan jaringan. Keduanya diawasi oleh Pimpinan Administrasi, untuk memantau kinerja arsiparis dan memantau distribusi arsip agar tidak dipergunakan oleh yang tidak berhak.

6) Retensi

Arsip yang tidak mempunyai nilai guna akan dihapuskan dan dimusnahkan oleh pengelola arsip, sementara yang dianggap masih berguna akan dipertahankan. Retensi arsip yang dilakukan bisa menggunakan Sistem Retensi 
Arsip Tradisonal ataupun Retensi Berdasarkan Fungsi dan Hubungan.

7) Pelestarian

Pelestarian arsip yang dimaksud adalah upaya mempertahankan kemampuan untuk menampilkan, menemukan kembali, memanipulasi dan menggunakan informasi digital dalam menghadapi perubahan teknologi yang berlangsung secara konstan.

Usaha-usaha yang dilakukan selain menjauhkan arsip dari hal-hal yang bisa menyebabkannya rusak, misalnya memasang Air Conditioner (AC) agar suhu di dalam ruangan tetap ideal $\left(18-22^{\circ} \mathrm{C}\right)$ dan alat ukur suhu ruangan untuk mengontrol suhu dan kelembaban.

Membersihkan ruangan arsip dan tempat penyimpanan arsip dari debu dan kotorankotoran kecil selalu dilakukan secara berkala dengan menggunakan vacuum cleaner.

Untuk mencegah kebakaran disiapkan juga smoke detector, hidrant dan tabung-tabung pemadam kebakaran. Usaha-usaha tersebut dilakukan untuk menjamin ketahanan dan kelestarian arsip.

Arsip di PT Elite Advertising memiliki peranan cukup penting karena membantu pimpinan dalam membuat perencanaan, pelaksanaan dan pengambilan keputusan. Arsip mempunyai peranan penting karena juga menjadi pedoman dalam penentuan arah dan pelaksanaan kerja secara keseluruhan. Arsip sangat mendukung pelayanan administrasi karena banyak informasiinformasi penting perusahaan terekam dalam arsip. Kelambatan penyediaan arsip yang dibutuhkan akan mengakibatkan kekacauan, pemborosan dan kelambatan pelayanan administrasi. Sebaliknya pengurusan arsip yang profesional akan meningkatkan kualitas keputusan pimpinan serta pelayanan administrasi yang efisien dan efektif dalam skala luas.

Beberapa keuntungan yang diperoleh perusahaan dalam penerapan E-Filing adalah :

a. Kegiatan pengindeksan, pencarian dan penemuan kembali arsip dapat dilakukan dengan cepat, fleksibel dan mudah dimodifikasi berdasarkan prosedur yang telah dikembangkan.

b. Pencarian secara full-text, dengan mencari file berdasarkan kata kunci dapat dengan mudah ditemukan.

c. Kemungkinan file hilang sangat kecil.

d. Menghematan pengeluaran organisasi, misalnya pengeluaran untuk kertas, tinta cetak (printer \& fotocopy)

e. Menghemat tenaga kerja (SDM), karena tidak pelu terlalu banyak karyawan yang harus dilibatkan, terutama dalam distribusi dokumen perkantoran.

f. Karena arsip-arsip disimpan secara digital, maka kerusakan arsip karena rusaknya dokumen dan print out bisa dihindarkan.

g. E-Filing yang diterapkan perusahaan cukup memudahkan dalam berbagi (sharing). Arsip dapat dibagikan melalui Local area Network dan Internet, sehingga transfer dokumen antar bagian di perusahaan juga lebih cepat dilakukan.

h. Memudahkan recovery dan back up arsip.

i. Meningkatkan kecepatan pengambilan keputusan oleh pimpinan.

Masalah dan Rekomendasi yang dihadapi dalam Implementasi E-Filing adalah :

a. Karena proses menciptakan, menyimpan, memodifikasi ataupun menghapus arsip sangat mudah dan bisa dilakukan dengan berbagai cara, maka muncullah kemungkinan arsip dimanipulasi (direkayasa). Untuk itu perlu ditentukan satu sistem pengamanan arsip agar tetap terjaga keasliannya dan tidak disalahgunakan.

b. Kesulitan sharing file karena adanya perbedaan format file maupun ketersediaan jaringan atau akses untuk share file. Untuk mengatasi hal ini perlu diusahakan ada sistem penyimpanan atau pengolahan E-filing dengan aplikasi yang seragam di perusahaan agar mereka yang membutuhkan dapat menerima arsip dengan baik.

c. Kemungkinan rusaknya file tanpa ada tanda-tanda sebelumnya, misalnya karena adanya serangan virus atau terhapusnya arsip tanpa disengaja. Hal ini bisa diatasi dengan memasang antivirus dan seringsering melakukan back up file ke dalam berbagai bentuk media penyimpanan.

d. Keterbatasan pegawai sebagai Sumber daya manusia yang mengoperasikan program aplikasi E-Filing. Rekomendai yang bisa diajukan adalah dengan memberikan pelatihan dan pengembangan kemampuan karyawan dalam bidang Information technology khususnya pengelolaan E-Filing.

\section{8) KESIMPULAN}

PT Elite Advertising sudah mengimplementasikan E-Filing yang berfungsi mendukung pelayanan administrasi sesuai tujuan perusahaan

Implementasi E-Filing membantu para petugas arsip dalam melakukan pengindeksan, pencarian dan penemuan kembali , terhindar dari kehilangan arsip, menghemat pengeluaran perusahaan , menghemat tenaga kerja, memudahkan share-file, memudahkan recovery dan back up sehinga sangat mendukung efektivitas dan efisiensi pelayanan administrasi.

Beberapa kendala yang perlu diatasi adalah perlunya didesain kembali sistem pengamanan arsip yang lebih baik, keseragaman aplikasi pengelolaan E-Filing sehingga mempermudah akses, serta memberikan pelatihan-pelatihan khusus bagi para pengelola arsip sehingga memiliki kemampuan yang baik dan lebih profesional dalam melaksanakan E-Filing.

\section{9) DAFTAR PUSTAKA}

Dokumen

1. Kamus Besar Bahasa Indonesia (KBBI). 
2. Peraturan Pemerintah No. 161 Tahun 1971 Tentang Pokok-pokok Kearsipan nasional.

3. Undang-undang NO. 7 Tahun 1971 Tentang Penyusutan Arsip dan Peraturan Pelaksanaanya.

\section{Buku-buku Ilmiah}

1. Abubakar, Hadi. 1991. Pola Kearsipan Modern Sistem Kartu Kendali. Jakarta : Djambatan.

2. Alamsyah, Zulkifli. 2003. Manajemen Kearsipan. Jakarta. PT. Gramedia Pustaka Utama.

3. Arikunto, Suharsimi. 2002. Prosedur Penelitian Suatu Pendekatan Praktek. Jakarta : Rineka Cipta.

4. Budiman, Muhammad Rosyid. 2009. Dasar Pengelolaan Arsip Elektronik. Jogjakarta, BPAD

5. Haryadi, Hendi. 2009. Administrasi Perkantoran untuk Manajer \& Staf. Jakarta; Visi Media

6. Indrajit, Richardus Eko.2005. E-Government in Action.Yogyakarta ; Andi

7. Madiana, Gina dan Iwan Setiawan. 1994. Kearsipan Kelompok Bisnis Dan Manajemen. Bandung : Armico.

8. Martono, Boedi. 1992. Penyimpanan Berkas Dalam Manajemen Kearsipan. Jakarta : Pustaka Sinar Harapan.

9. Martono, E. 1991. Rekord Manajemen Dan Filing Dalam Praktek Perkantoran Modern. Jakarta : Karya Utama.

10. Moekijat. 1995. Management Perkantoran. Bandung. CV. Mandar Maju.

11. --- 1985. Tata Laksana Kantor Bandung . Bandung. CV. Mandar Maju.

12. Sedarmayanti.2005. Tugas dan Pengembangan Sekretaris. Bandung: CV Mandar Maju

13. The Liang Gie, Drs. 2000. Administrasi Perkantoran Modern, Edisi Keempat. Yogyakarta. Liberty.

14. Wursanto. 1991. Kearsipan 2. Yogyakarta. Kanisius. 